\title{
Effect of Climate Variability on Agro-climatic Potential of Landscapes of the Chechen Republic
}

\author{
Sh Sh Zaurbekov ${ }^{1,2}$, L R Bekmurzaeva1, V V Bratkov³ ${ }^{3}$ T Kh Ozdieva1, and A A \\ Batukaev ${ }^{1}$ \\ ${ }^{1}$ Department of Ecology and Nature Management, M.D. Millionshchikov Grozny State Oil \\ Technical University, Grozny, Russia \\ ${ }^{2}$ Laboratory of Geology and Geoecology, Kh. Ibragimov Complex Institute of the Russian \\ Academy of Sciences, Grozny, Russia \\ ${ }^{3}$ Department of Geography, Moscow State University of Geodesy and Cartography, Moscow, \\ Russia
}

\section{Abstract}

The paper analyzes variability of the agro-climatic parameters of landscapes in the Chechen Republic, which are actively involved in agricultural production. The paper employs statistical and mathematical research methods. Due to climate aridization,

Corresponding Author:

Sh Sh Zaurbekov

eip-eco2017@yandex.ru

Received: 25 October 2019

Accepted: 15 November 2019

Published: 25 November 2019

Publishing services provided by Knowledge E

(c) Sh Sh Zaurbekov et al. This article is distributed under the terms of the Creative Commons

Attribution License, which permits unrestricted use and redistribution provided that the original author and source are credited.

Selection and Peer-review under the responsibility of the AgroSMART 2019 Conference Committee. agro-climatic conditions were found to deteriorate in 1965--2015 in the plain semi-desert and desert landscapes. Despite the improved thermal and moisture conditions in the plain steppe landscapes, the number of dangerous meteorological phenomena was observed to increase, including those detrimental to agriculture. Owing to the increased period of active vegetation of plants, agro-climatic conditions in the mountain-valley shrub-steppe landscapes of the republic improved compared to those observed in 1931--1960.

\section{Introduction}

Natural and climatic resources of the Chechen Republic are the most important factor affecting the agricultural specialization of the region. Variability of the climatic resources of individual regions can be attributed to global climate change. Despite a great number of studies on climate change in the Chechen Republic and the North Caucasus [1-10], the consequences of these changes for agriculture of the region are neglected. Therefore, we focused on the assessment of current agro-climatic conditions in the Chechen Republic. 


\section{Materials and Methods}

Climate change results in variability of such climatic parameters as temperature and precipitation. The changes of these parameters are mainly analyzed for individual years, seasons and/or months. For agricultural assessment of thermal resources, air temperature (minimum, average and maximum) is analyzed. G.T. Selyaninov proposed to use the sum of temperatures above $10{ }^{\circ} \mathrm{C}$, that is active temperatures that serve as an indicator of the heat supply during the period of active vegetation of agricultural crops. The sum of effective temperatures is also used to show the need of plants for heat, which is the sum of average daily temperatures calculated on the biological minimum required for the given crop (variety, hybrid) to develop. For example, when calculating the sum of effective temperatures above $10{ }^{\circ} \mathrm{C}\left(\Sigma \mathrm{t}>10^{\circ}\right), 10^{\circ} \mathrm{C}$ is subtracted from the average daily temperature per each day, and the residuals are added together. The conditionally accepted vegetation threshold for cold-resistant crops is $+5{ }^{\circ} \mathrm{C}$, for crops of the moderate band $+10{ }^{\circ} \mathrm{C}$, and for thermophilic crops $+15^{\circ} \mathrm{C}$. For natural vegetation of temperate latitudes, air temperature of $5{ }^{\circ} \mathrm{C}$ is considered to be the onset of spring development. The sum of effective temperatures in the growing season can be less than $1500^{\circ}$ for cold-resistant plants and more than $2000^{\circ}$ for thermophilic plants (2000--3000 for cotton and 3500--4000 for rice). The sum of effective temperatures is a practically valuable indicator that differs from the real one. In fact, photosynthesis even in tropical plants occurs at $5-7^{\circ} \mathrm{C}$, and in plants of the temperate zone it can be observed at temperatures below $0{ }^{\circ} \mathrm{C}$.

In addition to the amount of precipitation, various coefficients and indices are used to assess the moisture parameter. The most common coefficients are the hydrothermal coefficient introduced by G.T. Selyaninov and the moisture coefficient proposed by N.N. Ivanova. Hazardous hydrometeorological processes and phenomena affecting agriculture (atmospheric drought, high intensity precipitation, hail, significant wind speeds, etc.) are also analyzed.

The Chechen Republic exhibits different landscapes that are actively involved in agricultural production and cover the North Caucasus: plain semi-desert and desert, plain steppe, and mountain-valley shrub-steppe. Variability of agro-climatic conditions in these landscapes was assessed over the period of 1965--2015. Climate variability analysis was based on data from Naurskaya, Grozny, Gudermes and Shatoi meteorological stations. Indicators of variability of agro-climatic conditions calculated based on data from Naurskaya station are representative for semi-desert and desert landscapes, 
those obtained from Grozny and Gudermes stations are characteristic of steppe landscapes, and indicators calculated based on data from Shatoi station are characteristic of mountain-valley shrub-steppe landscapes of the republic.

\section{Results}

Analysis of annual and average monthly air temperature over the period of 1965--2015 based on data from all the stations shows the increased temperature compared to that observed in 1931--1960 (Table 1). Thus, in semi-desert and desert landscapes the annual air temperature increased by $0.4^{\circ} \mathrm{C}$, in steppe landscapes it increased by $0.5^{\circ} \mathrm{C}$, and in mountain-valley shrub-steppe landscapes the temperature rises by $0.3^{\circ} \mathrm{C}$. In the study period, an increase in the average temperature was observed in all months except April as compared to the norm. In April, the difference from the norm is negative and amounts to $--0.2{ }^{\circ} \mathrm{C}$ in semi-desert and desert landscapes, $--0.1^{\circ} \mathrm{C}$ in steppe landscapes, and $-0.3{ }^{\circ} \mathrm{C}$ in mountain-valley shrub-steppe landscapes. Cold months -- November, December, January, February and March -- significantly contributed to the temperature increase.

Analysis of the variability of the sum of active temperatures in 1965--2015 shows that the average value of the sum of active temperatures in semi-desert and desert and steppe landscapes is less than the norm, whereas in mountain-valley shrub-steppe landscapes this value is higher than the norm (Table 2 ). Thus, the growing period in semidesert and desert and steppe landscapes shortened by 3 and 2 days, respectively, which can be due to the fact that April (onset of the growing season) exhibited temperature lower than a long-term annual average temperature value. In contrast, the growing season in mountain-valley shrub-steppe landscapes lengthened by 10 days, which can be due to the fact that the maximum air temperature increased in the cold period and lengthened the growing season.

Analysis of critical temperatures over the period of 2005--2015 shows that the maximum temperature in summer has an adverse effect on crops. According to observations of agrometeorologists, since 2010, July and August have been characterized by unfavorable agro-climatic conditions due to dry and hot weather, lack of moisture in soil, and frequent dry winds.

A tendency to the shift of seasons can be observed across all the stations, when the hottest month is not July but August. In 2010 the hottest day was registered on September 1 at all the stations, when air temperature reached $40.0^{\circ} \mathrm{C}$ in semi-desert and desert landscapes, $40.0^{\circ} \mathrm{C}$ (Grozny) and $41.0^{\circ} \mathrm{C}$ (Gudermes) in steppe landscapes, 
and $37.0^{\circ} \mathrm{C}$ in mountain-valley shrub-steppe landscapes. Analysis of the minimum air temperature in 2005--2015 shows that extremely low temperatures "fit" in the calendar winter months. According to agrometeorological observations, damage to crops caused by low temperatures in winter was not observed during the study period. All the stations registered frosts in April, but there were no data on damage to agricultural crops.

Analysis of the variability of precipitation shows an uneven change in that the amount of precipitation in the territory of the Chechen Republic. The amount of precipitation in plain steppe and mountain-valley shrub-steppe landscapes increased by 30 and 24 $\mathrm{mm}$, respectively (Table 3). In plain semi-desert and desert landscapes, the amount of precipitation increased by $7 \mathrm{~mm}$ only. The maximum increase in the amount of precipitation was observed in June across all the stations.

In general, the hydrothermal coefficient and the moisture coefficient (Tables 4 and 5) indicate the stability of moisture conditions in the study area. Despite the changed amount of precipitation, the moisture indicators remained virtually unchanged. Thus, the hydrothermal coefficient increased on average by 0.05 in plain steppe landscapes and by 0.03 in mountain-valley shrub-steppe landscapes. In plain semi-desert and desert landscapes, this indicator remained unchanged. The moisture coefficient increased by 0.01 in semi-desert and desert landscapes, by 0.03 in steppe landscapes, whereas in mountain-valley shrub-steppe landscapes this coefficient decreased by 0.02 . This can be due to the increased evaporation as a result of the increased sum of active temperatures.

In 2010--2015, 52 hazardous hydrometeorological phenomena were observed in the territory of the Chechen Republic. In 2010--2011, damage to agriculture crops was caused by prolonged dry weather that affected the harvest of spring, tilled and industrial crops. In 2012, frequent intense rains delayed crop harvesting for 12--17 days, which resulted in partial blackening of the ear axes, grain shedding, lodging, and germination of grain in the ear (Table 6).

\section{Conclusions}

Thus, the study showed various changes in the agro-climatic potential of plain semidesert and desert, steppe and mountain-valley shrub-steppe landscapes in the territory of the Chechen Republic. Steppe landscapes exhibit a significant increase in air temperature by $0.5{ }^{\circ} \mathrm{C}$ and an increase in the amount of precipitation by $10 \%$ in Grozny and by $3.4 \%$ in Gudermes. As a result, the improved thermal and moisture supply in steppe landscapes increased the crop yield. In semi-desert and desert landscapes, 
TABLE 1: Air temperature variability in 1965--2015 across the stations ${ }^{a}$

\begin{tabular}{|c|c|c|c|c|c|c|c|c|c|c|c|c|c|}
\hline \multicolumn{14}{|c|}{ Naurskaya (semi-desert and desert landscapes) } \\
\hline & 1 & II & III & IV & $\mathrm{V}$ & VI & VII & VIII & IX & $x$ & $\mathrm{XI}$ & XII & Year \\
\hline Min & $--12,7$ & $--8,6$ & $--2,2$ & 7,4 & 14,7 & 19,3 & 20,4 & 20,9 & 15,3 & 6,1 & $--4,8$ & $--8,6$ & 9,3 \\
\hline Max & 3,0 & 4,0 & 8,8 & 14,8 & 20,2 & 24,9 & 27,1 & 28,0 & 22,2 & 15,1 & 8,0 & 4,7 & 13,0 \\
\hline Average & 2,1 & $--1,2$ & 4,1 & 11,2 & 17,2 & 21,8 & 24,3 & 23,7 & 18,5 & 11,3 & 5,1 & 0,3 & 11,2 \\
\hline Norm & $--2,4$ & $--1,9$ & 3,6 & 11,4 & 16,8 & 21,7 & 24,2 & 23,3 & 18,2 & 10,9 & 4,5 & $--0,2$ & 10,8 \\
\hline Diffe & 0,3 & 0,7 & 0,5 & $--0,2$ & 0,4 & 0,1 & 0,1 & 0,4 & 0,3 & 0,4 & 0,6 & 0,5 & 0,4 \\
\hline \multicolumn{14}{|c|}{ Grozny (steppe landscapes) } \\
\hline & 1 & II & III & IV & V & $\mathrm{VI}$ & VII & VIII & IX & $x$ & $X I$ & XII & Year \\
\hline Min & $--12,7$ & $--12,0$ & $--1,8$ & 7,1 & 14,1 & 18,8 & 21,6 & 20,3 & 15,3 & 6,4 & $--4,6$ & $--7,1$ & 8,6 \\
\hline Max & 2,7 & 4,1 & 8,8 & 14,6 & 21,1 & 25,0 & 26,1 & 28,9 & 21,4 & 14,7 & 7,5 & 4,3 & 12,6 \\
\hline Average & $--2,3$ & $--1,8$ & 4,0 & 11,0 & 16,9 & 21,4 & 24,0 & 23,5 & 18,4 & 11,1 & 4,9 & $--0,2$ & 10,9 \\
\hline Norm & $--3,1$ & $--2,4$ & 3,3 & 11,1 & 16,4 & 20,9 & 23,9 & 22,8 & 18,1 & 10,6 & 4,2 & $--0,6$ & 10,4 \\
\hline iffer & 0,8 & 0,6 & 0,7 & $--0,1$ & 0,5 & 0,5 & 0,1 & 0,7 & 0,3 & 0,5 & 0,7 & 0,4 & 0,5 \\
\hline \multicolumn{14}{|c|}{ Gudermes (steppe landscapes) } \\
\hline & 1 & II & III & IV & V & $\mathrm{V}_{\mathrm{I}}$ & VII & VIII & IX & $x$ & $X I$ & XII & Year \\
\hline Min & $--12,5$ & $--7,6$ & $--1,5$ & 7,2 & 14,4 & 19,2 & 21,8 & 21,3 & 15,8 & 6,7 & $--4,2$ & $--6,9$ & 9,2 \\
\hline Max & 3,1 & 5,0 & 9,2 & 15,4 & 20,2 & 25,0 & 27,9 & 28,0 & 22,8 & 16,2 & 8,7 & 5,0 & 13,3 \\
\hline Average & $--1,9$ & $--1,0$ & 4,4 & 11,3 & 17,2 & 22,0 & 24,8 & 24,1 & 19,0 & 11,8 & 5,6 & 0,4 & 11,5 \\
\hline Norm & $--2,3$ & $--1,4$ & 4,0 & 11,4 & 16,7 & 21,7 & 24,6 & 23,6 & 18,7 & 11,4 & 4,8 & $--0,1$ & 11,1 \\
\hline Difference & 0,4 & 0,4 & 0,4 & $--0,1$ & 0,5 & 0,3 & 0,2 & 0,5 & 0,3 & 0,4 & 0,8 & 0,5 & 0,4 \\
\hline \multicolumn{14}{|c|}{ Shatoi (mountain-valley shrub-steppe landscapes) } \\
\hline & 1 & II & III & IV & V & $\mathrm{VI}$ & VII & VIII & IX & $x$ & $\mathrm{XI}$ & XII & Year \\
\hline Min & $--12,4$ & $--8,5$ & $--2,6$ & 6,4 & 12,0 & 15,6 & 16,9 & 17,2 & 12,2 & 4,9 & $--5,1$ & $--7,2$ & 7,2 \\
\hline Max & 1,4 & 2,5 & 8,7 & 14,3 & 16,8 & 21,2 & 23,4 & 24,7 & 18,3 & 17,7 & 7,3 & 4,0 & 11,0 \\
\hline Average & $--3,1$ & $--2,1$ & 2,7 & 9,6 & 14,4 & 18,0 & 20,3 & 20,0 & 15,4 & 9,4 & 3,5 & $--1,3$ & 8,9 \\
\hline Norm & $--3,6$ & $--2,7$ & 2,1 & 9,9 & 14,1 & 17,8 & 20,1 & 19,5 & 15,1 & 8,9 & 3,0 & $--1,6$ & 8,6 \\
\hline ifference & 0,5 & 0,6 & 0,6 & $--0,3$ & 0,3 & 0,2 & 0,2 & 0,5 & 0,3 & 0,5 & 0,5 & 0,3 & 0,3 \\
\hline
\end{tabular}

${ }^{a}$ Hereinafter, min is the minimum temperature in 1965--2015; max is the maximum temperature in 1965--2015; average is the average temperature in 1965--2015; norm is the long-term annual average temperature values (reference data); difference is the difference between average and norm values.

TABLE 2: Variability of the period of active vegetation of crops in the Chechen Republic.

\begin{tabular}{|l|c|c|c|c|}
\hline & Naurskaya & Grozny & Gudermes & Shatoi \\
\hline Min & 3050 & 2934 & 3126 & 2469 \\
\hline Max & 4333 & 4337 & 4439 & 3671 \\
\hline Average & 3760 & 3692 & 3868 & 2949 \\
\hline Norm & 3854 & 3772 & 3903 & 2647 \\
\hline Difference & -94 & --80 & --35 & 301 \\
\hline $\begin{array}{l}\text { Vegetation period } \\
\text { deviation (days) }\end{array}$ & --3 & --3 & --1 & +10 \\
\hline
\end{tabular}

the increased air temperature (by $0.4{ }^{\circ} \mathrm{C}$ ) and the reduced amount of precipitation led 
TABLE 3: Variability of the amount of precipitation in 1965--2015 across the stations.

\begin{tabular}{|c|c|c|c|c|c|c|c|c|c|c|c|c|c|}
\hline \multicolumn{14}{|c|}{ Naurskaya } \\
\hline & I & II & III & IV & V & VI & VII & VIII & IX & $x$ & XI & XII & Year \\
\hline Min & 3 & 4 & 5 & 4 & 8 & 1 & 0 & 1 & 1 & 0 & 5 & 4 & 249 \\
\hline Max & 81 & 93 & 95 & 120 & 98 & 149 & 224 & 122 & 168 & 106 & 87 & 128 & 686 \\
\hline Average & 28 & 26 & 28 & 32 & 48 & 55 & 46 & 39 & 34 & 33 & 32 & 34 & 439 \\
\hline Norm & 24 & 28 & 30 & 33 & 49 & 48 & 48 & 34 & 33 & 35 & 37 & 33 & 432 \\
\hline Difference & 4 & --2 & --2 & --1 & --1 & 7 & --2 & 5 & 1 & --2 & --5 & 1 & 7 \\
\hline \multicolumn{14}{|c|}{ Grozny } \\
\hline & I & II & III & IV & V & VI & VII & VIII & IX & $x$ & XI & XII & Year \\
\hline Min & 1 & 5 & 3 & 4 & 17 & 1 & 5 & 0 & 4 & 0 & 5 & 5 & 253 \\
\hline Max & 63 & 56 & 56 & 107 & 122 & 185 & 175 & 159 & 190 & 152 & 104 & 94 & 784 \\
\hline Average & 22 & 21 & 24 & 37 & 57 & 75 & 57 & 46 & 38 & 38 & 30 & 27 & 472 \\
\hline Norm & 21 & 23 & 21 & 32 & 55 & 66 & 57 & 37 & 31 & 29 & 31 & 26 & 429 \\
\hline Difference & 1 & -2 & 3 & 5 & 2 & 9 & 0 & 9 & 7 & 9 & --1 & 1 & 43 \\
\hline \multicolumn{14}{|c|}{ Gudermes } \\
\hline & 1 & II & III & IV & V & VI & VII & VIII & IX & $x$ & $X I$ & XII & Year \\
\hline Min & 1 & 5 & 4 & 2 & 5 & 2 & 4 & 4 & 2 & 0 & 3 & 5 & 204 \\
\hline Max & 87 & 79 & 61 & 130 & 196 & 154 & 146 & 158 & 265 & 112 & 114 & 98 & 835 \\
\hline Average & 29 & 28 & 29 & 38 & 60 & 65 & 47 & 41 & 40 & 40 & 35 & 32 & 485 \\
\hline Norm & 26 & 30 & 27 & 35 & 63 & 55 & 46 & 39 & 37 & 38 & 41 & 32 & 469 \\
\hline Difference & 3 & --2 & 2 & 3 & --3 & 10 & 1 & 2 & 3 & 2 & --6 & 0 & 16 \\
\hline \multicolumn{14}{|c|}{ Shatoi } \\
\hline & I & II & III & IV & V & $\mathrm{VI}$ & VII & VIII & IX & $x$ & XI & XII & Year \\
\hline Min & 2 & 5 & 3 & 8 & 27 & 25 & 17 & 18 & 11 & 0 & 4 & 2 & 466 \\
\hline Max & 136 & 54 & 114 & 136 & 181 & 198 & 198 & 184 & 186 & 141 & 140 & 129 & 944 \\
\hline Average & 25 & 23 & 39 & 64 & 102 & 108 & 89 & 77 & 62 & 46 & 32 & 30 & 698 \\
\hline Norm & 28 & 24 & 35 & 60 & 99 & 101 & 89 & 76 & 59 & 39 & 32 & 32 & 674 \\
\hline Difference & --3 & --1 & 4 & 4 & 3 & 7 & 0 & 1 & 3 & 7 & 0 & -2 & 24 \\
\hline
\end{tabular}

TABLE 4: Variability of the hydrothermal coefficient over the period of 1965--2015.

\begin{tabular}{|l|c|c|c|c|}
\hline & Naurskaya & Grozny & Gudermes & Shatoi \\
\hline Min & 0,28 & 0,32 & 0,32 & 0,94 \\
\hline Max & 1,37 & 1,67 & 1,65 & 2,77 \\
\hline Average & 0,73 & 0,89 & 0,83 & 1,63 \\
\hline Norm & 0,73 & 0,81 & 0,80 & 1,60 \\
\hline Difference & 0,00 & 0,08 & 0,03 & 0,03 \\
\hline
\end{tabular}

to climate aridization. In mountain-valley shrub-steppe landscapes, the agro-climatic conditions improved compared to those observed in 1931--1960, which was due to an increase in air temperature by $0.3{ }^{\circ} \mathrm{C}$ and an increase in the amount of precipitation 
TABLE 5: Variability of the moistening coefficient over the period of 1965--2015.

\begin{tabular}{|l|c|c|c|c|}
\hline & Naurskaya & Grozny & Gudermes & Shatoi \\
\hline Min & 0,22 & 0,23 & 0,17 & 0,45 \\
\hline Max & 0,70 & 0,80 & 0,87 & 1,16 \\
\hline Average & 0,41 & 0,45 & 0,45 & 0,78 \\
\hline Norm & 0,40 & 0,40 & 0,43 & 0,81 \\
\hline Difference & 0,01 & 0,05 & 0,02 & $-0,02$ \\
\hline
\end{tabular}

TABLE 6: Damage to the agriculture of the Chechen Republic caused by hazardous phenomena (HP) and complex of meteorological phenomena (MPC) in 2010--2015.

\begin{tabular}{|c|c|c|c|}
\hline Date & Region & $\begin{array}{l}\text { Characteristics of HP } \\
\text { and MPC }\end{array}$ & Damage \\
\hline 5.08--21.08.2010 & $\begin{array}{l}\text { Steppe zones of the } \\
\text { republic }\end{array}$ & $\begin{array}{l}\text { MPC (prolonged dry } \\
\text { weather), no rains were } \\
\text { observed for } 16--20 \\
\text { days. The maximum air } \\
\text { temperature reached } \\
35--39{ }^{\circ} \mathrm{C} \text {. The } \\
\text { phenomenon lasted } 16 \\
\text { days. There was a } \\
\text { shortage of soil } \\
\text { moisture. }\end{array}$ & $\begin{array}{l}\text { Adverse effect of } \\
\text { prolonged dry weather } \\
\text { on the harvest of } \\
\text { spring, tilled and } \\
\text { industrial crops. }\end{array}$ \\
\hline 1.08--5.08.2011 & $\begin{array}{l}\text { Northern regions of the } \\
\text { republic (semi-desert } \\
\text { and desert landscapes) }\end{array}$ & $\begin{array}{l}\text { Atmospheric drought in } \\
\text { the northern regions of } \\
\text { the Chechen Republic } \\
\text { lasted } 4 \text { days. }\end{array}$ & $\begin{array}{l}\text { Adverse effect of } \\
\text { atmospheric drought } \\
\text { on the harvest of late } \\
\text { tilled crops. }\end{array}$ \\
\hline 9.07--16.07.2012 & Chechen Republic & $\begin{array}{l}\text { The combination of } \\
\text { intense, long-lasting } \\
\text { rains and } \\
\text { overmoistening of soil } \\
\text { delayed crop } \\
\text { harvesting (MPC). The } \\
\text { phenomenon lasted } 16 \\
\text { days. The amount of } \\
\text { precipitation was } \\
200--380 \% \text { of the } \\
\text { decade rate and led to } \\
\text { overmoistening. }\end{array}$ & $\begin{array}{l}\text { 12--17-day delay of crop } \\
\text { harvesting caused by } \\
\text { frequent intense rain. } \\
\text { Partial blackening of } \\
\text { the ear axes, grain } \\
\text { shedding, lodging, and } \\
\text { germination of grain in } \\
\text { the ear. }\end{array}$ \\
\hline
\end{tabular}

by $24 \mathrm{~mm} \mathrm{(3.6 \% )} \mathrm{that} \mathrm{led} \mathrm{to} \mathrm{a} \mathrm{10-day} \mathrm{increase} \mathrm{in} \mathrm{the} \mathrm{period} \mathrm{of} \mathrm{active} \mathrm{vegetation} \mathrm{of}$ agricultural crops.

\section{References}

[1] Bekmurzaeva, L.R., Zaurbekov, Sh.Sh. (2010). Assessment of climate variability of the East Caucasus semihumid low-valley hollow sites of the Chechen Republic. Science and Technology Miass: MCST, p. 73.

[2] Bratkov, V.V., Borlikov, G.M., Khukhlachiev, B.S. (2002). Seasonal dynamics of semiarid and arid landscapes of the South of Russia. Izvestiya VUZ North Caucasus 
region, vol. 3, pp. 72--79.

[3] Bratkov, V.V., Burim, Yu.V. (2006). Temporal structure of landscapes of the Stavropol Territory. Proceedings of Teberdinsky reserve, vol. 43, pp. 138--143.

[4] Bratkov, V.V., Salpagarov, A.D., Mokrousov, D.O. (2005). Seasonal landscape dynamics of Teberdinsky reserve. Moscow; Stavropol: Ileksa; Service School.

[5] Larionov, Yu.A. (2001). Changing the boundaries of agro-climatic subdistricts in connection with climate change. Ecological-geographical Bulletin of Southern Russia, vol. 2, pp. 104--106.

[6] Larionov, Yu.A. (2004). Changing the phenological terms of growth of agricultural crops in the North Caucasus Sustainable development of mountain areas. Vladikavkaz: Terek publishing house, pp. 494-495.

[7] Larionov, Yu.A., Lurie, PM, Panova, S.V. (2001). Prevention of the adverse effects of climate change in the Lower Don and the North Caucasus in the first half of the $X X I$ century. Sustainable development of mountain territories: problems of regional cooperation and regional policy of mountain regions. Vladikavkaz, pp. 454--455.

[8] Larionov, Yu.A., Panov, V.D., Panova, S.V. (2002). The climate of the Rostov Region at the end of the 20th and the first half of the 21st centuries. Ecological-geographical Bulletin of the South of Russia, no. 2, pp. 23--28.

[9] Lurie, P.M. (2002). Global climate change and river flow in the south of Russia. Ecological-geographical Bulletin of the South of Russia, no. 2, pp. 42--45.

[10] Lurie, P.M., Larionov, Yu.A., Panova, S.V. (2001). Prevention of the adverse effects of climate change in the Lower Don and the North Caucasus. Sustainable development of mountain areas. Moscow: Art Business Center, pp. 454--455. 